\title{
Klasik Realizm-Güvenlik İlişkisi Çerçevesinde Türkiye'nin İç Güvenlik Politikaları (1923-1960) ${ }^{a}$
}

\author{
Ozan Kavsiraci ${ }^{\mathrm{b}}$
}

\section{Özet}

Devletlerin inşa ettikleri güvenlik kültürü, zamanla sosyal bir gerçeklik haline gelse de değişmesi ve çeşitlenmesi olanaklıdır. Çünkü aktörlerin çıkarları değiştiğinde güvenlik ve tehdit kavramsallaştırmasının da değişmesi beklenmektedir. Türkiye'nin tehdit algıları ve güvenlik politikalarının da dönemsel kırılma noktalarından geçtiğini ifade etmek doğru olacaktır. Türkiye Cumhuriyeti, Osmanlı İmparatorluğu ile sosyal pratikler (etkileşim) yoluyla inşa etmiş bir aktördür. Bu sebeple yeni Türkiye Cumhuriyeti'nin tehdit kavramsallaştırması da Osmanlı Devleti ile olan sosyal etkileşimler sonucu oluşmuştur. Bu çalışmada Türkiye' nin erken cumhuriyet döneminden itibaren güvenlik ajandasında yer alan iç güvenlik tehditleri ve bu tehditlere karşı oluşturulan güvenlik politikaları incelenmiştir. Bu kapsamda devlet arşivlerinde yer alan iç güvenlik içerikli belgelere ulaşılarak, devletin güvenlik politikalarını yansıtan birincil kaynaklar kullanılmıştır. Türkiye'nin güvenlik politikalarındaki içe dönük güvenlik politikalarına zemin hazırlayan faktörler özelinde değerlendirmeler yapılmış ve devletin geleneksel güvenlik pratiklerinde meydana gelen değişimler ele alınmıştır. Sonuç olarak çalışmada, Türkiye'nin varlığına yönelik iç tehdit unsurları ve bu tehditlere karşı geliştirilen iç güvenlik politikalarının realizm teorisi çerçevesinde analizi yapılmıştır.
Anahtar Kelimeler

Realizm

Tehdit

Güvenlik

Türkiye

Makale Hakkında

Geliş Tarihi: 08.10.2019

Kabul Tarihi: 12.10 .2020

Doi: $10.18026 /$ cbayarsos.631075

\section{Domestic Security Policy of Turkey in the Framework of Classical Realism and Security Relations (1923-1960)}

\begin{abstract}
Although the security culture that states have built over time has become a social reality, it is possible to change and diversify. Because when the interests of actors change, the conceptualization of security and threat is expected to change. It will be correct to state that Turkey's threat perceptions and security policy passed the periodic breaking points. Republic of Turkey is an actor who is built through social practices (interactions) with Ottoman Empire. Therefore, the threat conceptualization of the Republic of Turkey was formed interactions with the Ottoman Empire. In this study, Turkey's domestic security threat since the early republican period and security policies created against these threats is explained. In this context, the primary sources reflecting the security policies of the state were used. Factors that affect to domestic security policy in Turkey and the changes in traditional security practices of the state is reviewed. As a result, the internal threat elements to the existence of Turkey is analyzed in the framework of theory of realism.
\end{abstract}

Keywords

\section{Realizm \\ Threat \\ Security \\ Turkey}

\section{About Article}

Received: 08.10.2019

Accepted: 12.10 .2020

Doi: $10.18026 /$ cbayarsos.631075

\footnotetext{
a Bu makale yazar tarafından Polis Akademisi Başkanlığı, Güvenlik Bilimleri Enstitüsünde tamamlanmış olan “1980 Sonrası Dönemde Türkiye'deki İç Güvenlik Politikalarının Analizi" adlı doktora tezinden üretilmiştir.

b Dr. Öğretim Üyesi, Polis Akademisi Başkanlığı, ORCID: 0000-0001-6351-3725, e-mail: ozankavsiraci@gmail.com.
} 


\section{Giriş}

Tarihsel gelişmelerin her evresinde sıkça dile getirilen güvenlik kavramı, toplumsal yaşam akdinin gereği, beka durumunun devamı ve devletler için temel meşruiyet kaynağı olarak karşımıza çıkmaktadır. Maslow'un ihtiyaçlar piramidi güvenliği, insanların yeme, içme gibi temel ihtiyaçlarından sonra en önemli kavram olarak işaret etmiş olsa da, günümüzde güvenlik temel ihtiyaçlarla birlikte değerlendirilebilecek bir duruma gelmiştir. Dinamik bir yapıya sahip olan güvenlik kavramı, özne, tehdit, risk, endişe gibi değişkenler ve geleceğe yönelik beklentilerle açıklanabilen, çok değişkenli ve tartışmalı bir kavramdır (Birdişli, 2011, s. 150). Devletler için tanımlanan güvenlik algısı söz konusu olduğunda, güç ve çıkar değişkenleri ağırlık kazanmaktadır. Bu bakış açısı ile değerlendirildiğinde güvenlik, devlet bekasının korunması ve sürdürülmesi anlamı taşımaktadır. Başka bir ifadeyle, devletlerin varlıklarını sürdürmeleri ve korumalarına yönelik bir veya birden fazla içsel ya da dışsal tehdidin bulunmaması veya varlıklarını sürdürmeleri ve korumalarına yönelik tehdit algısı ve tahminlerinin bulunmaması olarak ifade etmek mümkündür (Dedeoğlu, 2014, s. 34).

Güvenlik tanımını kesin çizgilerle belirlemek mümkün değildir. Çünkü güven hissi, içinde bulunulan zamana ve şartlara göre değişkenlik göstermektedir. Göreceli olan bu durum güvenlik kavramının objektif olmasının yanı sıra, sübjektif ve açık uçlu olduğunu da göstermektedir. Objektif ve sübjektif güvenlik fikirlerinin sahibi Arnold Wolfers'a göre objektif güvenlik, "Eldeki değerlere yönelik tehditlerin yoklŭ̆u", sübjektif güvenlik ise, "Eldeki değerlerin tehdit edildiğine yönelik bir korkunun yokluğg" olarak tanımlanmaktadır. Güvenliğe ilişkin çalışmalara bakıldığında; genel olarak “kimin güvenliği? Kim tarafından güvenlik?" ve "hangi tehditlere karşı güvenlik?” sorularına cevap arandığı görülmektedir. Güvenlik kavramının özne, tehdit ve politika çerçevesinde çok boyutlu olarak analiz edilmesi, kavramın daha iyi anlaşılmasına hizmet etmektedir (Akgül, 2011, s. 45).

Uluslararası ilişkiler disiplini içerisinde gelişim gösteren güvenlik çalışmalarının başlangıç noktasını, büyük kayıplar yaşanmasına karşın bir türlü vazgeçilemeyen devletlerarası savaşlar oluşturmaktadır. Çatışma-uzlaşma ilişkisi ve devletlerin güçlenerek diğer devletleri egemenlik altına alma girişimleri, güvenlik çalışmalarının ilk resmi yapısını ortaya çıkarmıştır. Devletlerin savaşları kazanma yöntemleri, savaş sonuçlarının kazanan ve kaybeden devletler üzerindeki etkileri, barış arayışları ve savaşların sebep olduğu güvenlik kaygıları, güvenlik çalışmalarının temel inceleme konularını oluşturmuştur (Dedeoğlu, 2014, s. 27-40). Bu durum, 20. Yüzyılın son yarısına kadar güvenlik analizlerinin, devletlerin stratejik varlıklarını korumaya yönelik yapılmasını tetiklemiştir. Bu çerçevede devletlerin, varlıklarını korumak, sürdürmek ve hedeflerine ulaşmak için milli güvenlik politikası olarak adlandırılan plan ve yol haritaları oluşturduğu görülmektedir.

Devletlerin milli güvenliklerine ilişkin tanımlamaları; coğrafi şartlar, jeopolitik konum, toplumsal ve kültürel yapılar, tarihi miras ve işbirliği girişimleri noktalarında ayrışmaktadır (Gün, 2014, s. 21). Türkiye'nin iç güvenlik bileşeni özelinde, milli güvenlik kavramının unsurlarını aşağıdaki şekliyle belirtmek mümkündür (Ernam, 1972, akt; Gürpınar, 2016, s. 12):

a) Anayasa ve diğer yasal metinlerle belirlenmiş devlet düzenine tehdit oluşturacak faaliyetler (Kamu Düzeni Vurgusu),

b) Devletin savunma gücünü zayıflatmaya yönelik hareketler, 
c) Ülkenin ve milletin birlik, beraberlik ve bütünlüğünü tehdit eden veya etmesi muhtemel faaliyetler.

Milli güvenlik algısı ve politikalarının inşasında, tehdit ve risk kavramları önem kazanmaktadır. Tehdit ve risk ifadeleri birbirlerine yakın anlamlar içerse de farklı durumları ifade etmek için kullanılan kavramlardır. Tehdit, tarihin her döneminde, önceden tahmin edilebilen ve mücadele edilebilir bir kavram olarak kabul edilmektedir. Realizmin ifade ettiği üzere, devletler birbirleri için tehdit olarak algılanmış, taraflar asker sayıları ve savaş araçları çerçevesinde güvenlik politikaları geliştirerek birbirleri ile mücadele etmişledir (Çalkıvık, 2014, s. 296). Dolayısı ile tehdit, güvenlik sorunlarının sebep olabileceği ve önceden tahmin edilebilen potansiyel zararlar olarak tanımlanmaktadır. Risk kavramı ise tehdit kavramının aksine, belirsizliği, bilinmezliği ve kontrol edilemezliği ifade etmektedir. Risk bir olasılıktır. Tehdit ve tehlikeler risk kavramını kendi içinde gizlemektedir (Çalkıvık, 2014, s. 296). Türkiye Cumhuriyeti'nin ilk yıllarından itibaren güvenlik politikalarının özellikle beka, savunma ve toprak bütünlüğüne yönelik tehdit algıları çerçevesinde inşa edildiğini söylemek mümkündür.

$\mathrm{Bu}$ çalışmada, Türkiye Cumhuriyeti'nin üzerine inşa edildiği iç güvenlik endişeleri analiz edilmiştir. Birinci bölümde realizm ve güvenlik açılamaları incelenmiş, ikinci bölümde Türkiye'nin güvenlik kültürünün inşa sürecinde etkili olan tehdit unsurları değerlendirilmiştir. Üçüncü bölümde devletin resmi belgelerinde tespit edilen güvenlik nesnelerinin dönemin hâkim güvenlik paradigmaları ve realizm ile ilişkileri incelenmiştir. Türkiye'nin iç güvenliğe yönelik tehdit algısı, devlet arşivlerinden elde edilen resmî belgeler 1şığında tahlil edilmiştir. Devlet arşivlerindeki resmi belgelerde ifade edilen güvenlik politikalarının içerik analizi yapılarak hangi tehditlerin Türkiye' nin iç güvenlik ajandasına yer aldığı tespit edilmiş ve bu tehditlere yönelik açılamalara yer verilmiştir.

\section{Klasik Realizm ve Güvenlik}

İnsan tabiatına ait yasaları, devletlerarası sistemle ilişkilendiren realizm genel olarak dünyayı olduğu gibi kabul etme üzerine kuruludur. Uluslararası sistemin normatif unsurlar; değerler, idealler, normlar, söylemler ve duygulardan arındırılarak, olması istenilen uluslararası sistemin değil, var olan sistemin incelenmesi gerektiğini ileri sürmektedir. Realizm, Thomas Hobbes'un insan doğasının kötü ve günahkâr olduğu varsayımından yola çıkarak, aktörlerin çıkarları doğrultusunda hareket ettiği ve devletlerarasındaki güç mücadeleleri üzerinde durmaktadır.

Thomas Hobbes siyaset felsefesinin temeli olan "Toplum Sözleşmesi" teorisi ile devletlerin varlık nedenini genel güvenliğin arttırılması olarak görmektedir. Hobbes "Doğa Hali" kavramı ile egemen siyasi otoritenin bulunmadığı ve insanların bir arada yaşadığı farazi bir toplumu ifade etmektedir. Hobbes'un “Doğa Hali” anlayışında, insanlar doğuştan kötü, çıkarcı ve bencildir. Herkesin birbirleriyle zaman gözetmeksizin çatışma ihtimali bulunmaktadır. Sürekli rekabet ve çatışma riski içinde bulunan rasyonel bireyler, kaotik ortama son vermek için kendi iradeleriyle egemenliklerinden vazgeçerek, yetki ve güçlerini üst siyasi irade olan Leviathan'a devrederler. Leviathan'ın vatandaşlarına karşı tek 
sorumluluğu bireylerin güvenliklerini sağlamaktır (Hobbes, 2016, s. 20-22, Emekliler, 2011, s. 105-111). Hobbes'un güvenlik anlayışında, devlet güvenliği, birey güvenlinden önce gelir. Devletin bağımsız ve güvende olması beraberinde vatandaşların da güvende olmasını sağlar. Devletlerarası sistem, bireyler arasındaki doğa haline atıf yapılarak ifade edilmektedir. Devletlerarası ilişkiler sıfır toplamlı bir oyundur ve aralarında güç, çıkar mücadelesi olan devletler, doğa durumunda diğerinin düşmanı konumundadır.

Thukydides'in "Pelopennessos Savaşları" adlı eserindeki, Atinalılar ile Melanlılar arasındaki anlaşmazlığın çözümüne yönelik, Melan temsilcilerinin hakkaniyet ilkesine uygun olarak çözüm önerilerine, Atinalıların "Güçlüler yapacaklarını yaparlar ve zayıflar katlanmaları gerekene katlanırlar." cevabı realist ekolün çıkış noktasını anlatmaktadır (Thukydides, 2017, s. 18-21, Çıtak ve Şen, 2014, s. 31-32). Yunan şehir devletleri arasındaki sürekli savaş tehdidi ve devletlerarasında karar verici bir üst otoritenin olmayışı anarşi olarak isimlendirilen kaotik bir düzene vurgu yapmaktadır.

Hans Joachim Morgenthau'nun "Politics Among Nations" adlı çalışması modern realist teorinin kitabı olarak yorumlanmaktadır. Morgenthau ilk dönem düşünürlerinden esinlenerek, insan doğası, devletlerin güç mücadelesi, ulusal çıkar konuları üzerinde durmuştur. Morgenthau, realizmi altı temel ilke altında özetlemektedir. Bu ilkeler (Balta, 2014, s. 119-120):

a) Devletlerarası siyaset, insan doğasını açıklayan nesnel yasalarla ifade edilmektedir. İnsanlar arasındaki çıkar mücadelelerinden kaynaklanan kaos, uluslararası sistemde, üstün bir otorite eksikliğinden kaynaklanan anarşi ile örtüşmektedir.

b) Realizme rehberlik eden kavram, güç cinsinden ifade edilen çıkar kavramıdır.

c) Ulusal çıkar, değişmeyen, sabit bir kavram değildir. Tarihin farklı dönemlerinde siyasal koşullara ve uluslararası sistemin baskısına bağlı olarak ulusal çıkar kavramı da değişim göstermektedir.

d) Realizm ahlaki ilkeleri reddetmez. Ancak bu ilkelerin olduğu gibi devlet davranışlarına uygulanamayacağını savunur. Devleti yönetenlerin temel ilkesi devletin ve milletin bekasıdır.

e) Realizm, bir ulusun kendine özgü değerlerini, evrensel değerler olarak gösterilmesini reddeder. Bir ulusun çıkarları, rasyonel fayda / maliyet hesabına göre belirlendiği için, evrensel ilkelerle uyumlu olması beklenemez.

f) Morgenthau'ya göre uluslararası ilişkiler bağımsız bir disiplindir. Analiz birimi ulusdevlet, inceleme araçları ise güç cinsinden ifade edilen ulusal çıardır.

Realist teori düşünürlerinin söylemlerine göre; devletler, realizmin temel ve kalıcı aktörleridir. Çıkar ve güç mücadelesi insanlar arasındaki temel istektir. Devletler insanlardan teşkil olduğu için, insan doğası, devletlerin davranışlarına sirayet etmektedir. Uluslararası karar verici bir otoritenin olmayışı, güç siyaseti ile birleşince, uluslararası sistemin anarşik yapılanmasına neden olur. Bu kaotik ortamda, devletler amaçlarını gerçekleştirmek için güç kazanmak zorundadırlar. Devletler için gücün kaynakları; jeopolitik konum, doğal kaynaklar, askeri hazırlık, diplomasi, nüfus ve endüstridir. Morgenthau güç kavramını, caydırıcılık kapasitesi olarak da tanımlamaktadır. Güç ve güvenliğin eşanlamlı olarak kullanılması ve askeri gücün ön plana çıkarılmasının nedeni de caydırıcılık ile açıklanmaktadır. Ulusal çıkar kavramı ile ilişkilendirilen güç, devlete yönelik saldırıları caydırma kapasitesidir. Devletlerin niyetlerinde belirsizlikler olması nedeniyle, bir devletin gücünü arttırması, askeri hazırlıklarını büyütmesi, 
diğerleri tarafından tehdit olarak algılanacaktır. Tehlike altında olduğunu düşünen diğer devletler, kendilerini korumak için güçlerini arttırma yoluna gidecek, bu durum da ilk devletler tarafından tehdit olarak algılanacaktır. Güvenlik ikilemi olarak adlandırılan bu sarmal, devletlerarasinda gereksiz savunma tedbirlerinin artarak devam etmesine neden olmaktadır (Eralp, 2014, s. 56).

Realistler güvenlik tehdidinin içeriği konusunda ortak bir paydada birleşirler. Bir tehditten bahsetmek için taraf devletlerden birinin ya da tümünün kuvvet kullanımının söz konusu olması gerekmektedir (Akgül-Açıkmeşe, 2011, s. 50). Güç ve çıkar kavramları üzerine açıklamalarda bulunan realist teoride, temel kavramların çerçevesinin kesin olarak tanımlanmaması eleştirilen tartışmalı konudur. "Yüksek politika" ve "alçak politika" ayrımına giden realizme göre, askeri hazırlık, savaş ve güvenlik konuları, birincil derecede öneme sahip yüksek politika alanı kabul edilirken, toplumsal, kültürel, ekonomik vb. konular alçak politika alanını oluşturmaktadır (Aydın, 2004, s. 50-58).

İkinci Dünya Savaşı'nın etkisiyle modern anlamda şekillenen klasik realizm, günümüzde halen devletlerarasında yaşanan pek çok gelişmeyi açılamakla beraber, küreselleşme sürecinde yaşanan siyasi, kültürel, ekonomik vb. nedenler neticesinde birçok yönden de eleştirilmektedir. İnsan doğasına kötümser bakış açısı, sadece çatışma ve savaşı açıklamakla yetinerek, barış ve iş birliğini açıklamada yetersiz kalması, devletlerin giderek artan karşılıklı bağımlılı̆̆ını savunan araştırmacılar tarafından eleştirilmektedir.

\section{Türkiye'de Tehdit Algısının Gelişimine Etki Eden Unsurlar}

Türkiye Cumhuriyeti'nde tehdit algısının inşa sürecini, temel olarak tarihsel bağlantı, stratejik ve coğrafi özellikler ekseninde açılamak mümkündür. Tarihsel bağlantı noktasında; Osmanlı İmparatorluğu'nun son dönemlerinde özellikle Birinci Dünya Savaşı ve sonrasında yaşanan işgal tehdidi, toprak kaybetme korkusu ve farklı kimlik temellerinde yaşanan terk edilme endişelerinin Türkiye' nin güvenlik ajandasında da yer aldığı görülmektedir (Aydın ve Ereker, 2014, s. 129). Birinci Dünya Savaşı'na giden süreç, Osmanlı İmparatorluğu'nun yabancı devletlere karşı savunmacı ve güç dengesi siyasetini benimsemesini zorunlu kılmıştır. Bu durum Türkiye Cumhuriyeti'nin kuruluşundan itibaren "Sevr Korkusu” şekliyle tezahür eden güvenlik endişesinin, Türkiye'nin ulusal güvenlik politikalarına hâkim olmasına neden olmuştur (Aktaş, 2011, s. 27 ve Aydın, 2003, s. 165-166). Kültür kavramının verili ve değişmez olarak kabul etmek mümkün değildir. Kültürün bizatihi kendisi, toplumlar ve devletlerarası etkileşimler sonucunda oluşmuştur. Bu sebeple Türkiye Cumhuriyeti'nin güvenlik kültürünün de bağımlı bir değişken olarak düşünülmesi gerekmektedir (Oğuzlu, 2015, s. 226). Osmanlı İmparatorluğu'nun özellikle son dönemlerinde, diğer devletlerle yapılan savaşlar, kazanılan zaferler, yaşanan mağlubiyetler ve coğrafi şartlar Türkiye Cumhuriyeti için güvenlik kültürünün oluşumunda belirli davranış kodlarının gelişimine etki etmiştir.

Türkiye'nin stratejik ve politik konumu, Osmanlı İmparatorluğu'ndan miras kalan tehdit algısının yanında Türkiye'nin tehdit algısına etki eden diğer önemli bir unsurdur (Bilgin, 2005, s. 184). Türkiye'nin Avrupa, Afrika ve Asya arasındaki bağlantının kesişim noktasında, önemli deniz yolu limanlarına sahip olması ve Avrupa ve Asya arasındaki geçiş güzergâhında yer alan boğazlara hâkim olması, Türkiye açısından önemli fırsatlar ortaya çıkarmış olsa da 
Türkiye'nin bu konumu aynı zamanda, önemli güvenlik sorunlarını da tetiklemiştir. Türkiye'nin coğrafi anlamda fırsatlar doğuran stratejik konumu, çevresinde istikrarsızlık, çatışma üreten, farklı ideoloji ve hedefleri olan ülkeler açısından değerlendirildiğinde Türkiye için güvensizlik hissi üreten bir faktör olmaktadır.

Türkiye'nin tehdit algısına etki eden diğer bir faktör batılılaşma sürecidir. Türkiye'nin özellikle iki dünya savaşı arasındaki süreçte batılı devletlerle denge siyaseti sürdürmesi, batı kimliği ve kültürünü, Türkiye'nin kendi ulusal güvenlik politikalarında önemli bir unsura dönüştürmüştür (Aydın ve Ereker, 2014, s. 131). İki dünya savaşı arası dönemde SSCB'nin Türkiye Cumhuriyeti'ne yönelik boğazlar konusunda yeni koşullar diretmesi, Türkiye'nin güç politikasına yönelmesini ve batı ile pragmatik ilişkiler kurmasını tetiklemiştir. Bu durum, Türkiye'yi, dönemin önemli bir paradigması olan antikomünizmin önde gelen taşıyıcılarından biri haline getirmiştir (Babaoğlu, 2015, s. 165).

Türkiye'nin erken cumhuriyet döneminde iç güvenliğe ilişkin tehdit algıları, yukarıda ifade edildiği üzere, Osmanlı İmparatorluğu'ndan miras kalan tehdit genleri, çevre ülkeler ile geçmiş tecrübeler, realist güvenlik algısının etkisiyle, iç ve dış güvenliğin birbiri içinde çözünmesi şeklinde gelişme göstermiştir (Balkan, 2007, s. 45). Devletin iç güvenlik çerçevesinde geliştirdiği politikalar, realizmin birincil güvenlik aktörü olarak tanımladığı ve geçmişte olumsuz tecrübeler yaşanan devletlerden gelebilecek tehditlerin üzerine inşa edilmiş, toprak bütünlüğüne dayalı güçlü bir egemenlik anlayışı ve askeri strateji oluşturma siyaseti üzerine gelişmiştir.

\section{Türkiye'de İç Güvenliğe Yönelik Tehdit Algıları ve Politikalar}

Türkiye'de erken cumhuriyet dönemi iç güvenlik politikaları, resmi ideolojiye tehdit oluşturması muhtemel unsurlar üzerine şekillenmiştir. Birinci Dünya Savaşı sonrası Sevr Antlaşması ile Anadolu topraklarının bölünmesi tasarlanmış fakat başarılı olunamamıştır. Anadolu topraklarında kurulan Türkiye Cumhuriyeti için "Sevr Tezgâhı" ile tasarlanmış olan toprak kaybetme ve bölünme ihtimali, ulusal güvenlik politikalarının temelini oluşturmuştur. Türkiye'nin konumu ve doğal kaynakları itibariyle, tarihi açıdan büyük güçlerin rekabet alanı olan bölgelerin kesişme noktasında yer alması, Türkiye'nin güvenlik algılamalarında realizmin temel vurgusu olan yabancı devlet tehdidi unsurunu sürekli olarak güncel tutmuştur (Gül, 2016, s. 308).

Aşağıdaki tabloda yabancı devletlerle işbirliği yaparak, devletin aleyhine hareket eden kişilerin tespit edildiği ve işbirliklerine ilişkin bilgilerin kayıt altına alındığı görülmektedir. Devletin aleyhine hareket ettiği tespit kişilerin bu faaliyetleri istihbari çalışmalar kapsamında takip edilmiş ve devlet arşivlerinde kayıt altında tutulmuştur. Aşağıda Devlet Arşivlerinden elde edilen 1928 yılı bölgesel istihbarat bilgilerine yer verilmiştir. 
Tablo 1. İzmir ve Balıkesir, Aydın, Trabzon Bölgelerindeki Kişilere İlişkin İstihbarat Çalışmaları

\begin{tabular}{|c|c|c|}
\hline Bölge & İsim & Açıklama \\
\hline Balıkesir / Bandırma & Avukat Hamdi & $\begin{array}{l}\text { Tatardır. Çerkezlerle çalışır. Çerkez } \\
\text { Ethem'in mahiyetinde bulunmuştur. }\end{array}$ \\
\hline Balıkesir / Balya & Saadettin Oğlu Talat & İngiliz muhipler cemiyetinin mürevvici. \\
\hline Balıkesir/ Burhaniye & Reis Ali Ulvi & Giritli Yunanlılara tercümanlık yapar. \\
\hline İzmir & Yunus Zade Raşit & $\begin{array}{l}\text { Yunanlılarla teşriki mesai etmiş. Bir } \\
\text { takım su-i istimallerde bulunmuştur. }\end{array}$ \\
\hline İzmir & Hasan Basri & $\begin{array}{l}\text { Yunanistan'a gider gelir. Yunan } \\
\text { casuslarla temas eder. Şüpheli bir } \\
\text { adamdır. }\end{array}$ \\
\hline İzmir & Nazım & $\begin{array}{l}\text { İkinci grup azasından komünistlikle } \\
\text { alakasından hakkında takibat yapılmış. }\end{array}$ \\
\hline İzmir / Urla & Baytar Zeki & $\begin{array}{l}\text { Bayrağımızı çiğnemiştir. Yunanlıların } \\
\text { baytarlığını yapmıştır. Firar etmiş ve } \\
\text { mübadil sonucu gelmiştir. }\end{array}$ \\
\hline İzmir / Urla & Filorinalı Salih & $\begin{array}{l}\text { Yunanlılar lehine, ordumuz aleyhine } \\
\text { tahkikat. } \\
\text { İngilizlere Casusluk. Çerkez Ethem ile }\end{array}$ \\
\hline İzmir / Urla & Fettah Oğlu Hasan & $\begin{array}{l}\text { Yunanistan'a firar. Aftan istifade } \\
\text { gelmiştir. }\end{array}$ \\
\hline İzmir / Dikili & $\begin{array}{l}\text { Bakkal Arnavut } \\
\text { Muharrem }\end{array}$ & $\begin{array}{l}\text { Yunan ve İngilizlere yardım etmiş } \\
\text { casustur. }\end{array}$ \\
\hline Aydın / Söke & $\begin{array}{l}\text { Postacı Zade Necip } \\
\text { B. }\end{array}$ & $\begin{array}{l}\text { Aydın'da maruf bir şahsiyettir. } \\
\text { Yunanlarla çalışmıştır. }\end{array}$ \\
\hline Trabzon & Neşat & $\begin{array}{l}\text { İngilizler hesabına çalışmış, tarassut } \\
\text { altında bir adam. } \\
\text { Komünist mektebinden çıkmış, }\end{array}$ \\
\hline Trabzon & Rıfkı Kulaç & $\begin{array}{l}\text { Rus konsülüshanesinden para } \\
\text { almaktadır. }\end{array}$ \\
\hline Trabzon & İbrahim & $\begin{array}{l}\text { İngilizlerin Trabzon havalisinde sayılı } \\
\text { casuslardandır. }\end{array}$ \\
\hline Silifke & Tahir B. Oğlu Sadık & $\begin{array}{l}\text { Emniyetçe malum, Yunanistan'a gider } \\
\text { gelir. }\end{array}$ \\
\hline
\end{tabular}

Kaynak: T. C. Cumhurbaşkanlığı Devlet Arşivleri Başkanlığı, Belge No: 490-1-0-0 / 63-240-4

Osmanlı Devleti'nin son dönemlerinden itibaren inşa edilen İngiltere, Yunanistan vb. yabancı devlet kaynaklı tehditlerin, Türkiye Cumhuriyeti'nin bekası için de önemli bir tehdit unsuru olmaya devam ettiği görülmektedir. Dış müdahalelere yönelik endişeler, azınlıkların ve ülke içinde diğer devletlerle ilişkisi bulunan vatandaşların denetim ve kayıt altında tutulmasına neden olmuştur.

Yunanistan'da, Türkiye aleyhine bazı faaliyetlerin meydana geldiği ve Yunan-İtalyan yakınlaşması ile Yunanistan'ın bu faaliyetlerine ilişkin İçişleri Bakanı Şükrü Kaya imzalı 
raporda şu ifadelere yer verilmiştir (T.C. Cumhurbaşkanlığ Devlet Arşivleri Başkanlığı, 1928, Belge No: 30-10-0-0 / 254-710-35):

Yunanistan başbakanı Venizelos ve iki bakanının kâtipleri arasında geçen bir konuşmada; "Yakında Çatalca'ya doğru gideriz. Venizelos çok mühim bir adamdır. Musolini ile çok gizli ve ehemmiyetli bir surette anlaşmıştır. İtalya'nın Türkiye'ye karşı dostluğu ve itilafı calidir". Iffadeleri geçmiştir. Yunanlılar bilhassa ordu mensupları, bu günlerde Türkiye'den gelenlerle pek meşgul oluyorlar ve takipten geri kalmıyorlar.

Türkiye'nin resmi belgelerine yansıyan yukarıdaki bilgiler, Türkiye'nin tarihi ve bölgesel olarak mücadele içinde olduğu yabancı devletlere yönelik ilişkiler birikiminin iç güvenlik politikalarını etkilediğini göstermektedir.

Yalta Konferansı sonrasında niyetini resmi olarak dillendiren ve Türkiye'ye Boğazlar konusunda nota veren Sovyetler Birliği'nin Türkiye toprakları üzerindeki tutumu ve Sovyetler Birliği'nin temsil ettiği komünist ideolojinin yayılma tehlikesi karşısında, Türkiye'nin Sovyetler Birliği ve komünizm özelinde, iç güvenlik tehditlerine yönelik tedbirlere önem verdiği görülmektedir.

10 Haziran 1932 tarihli Cumhurbaşkanı Mustafa Kemal Atatürk imzalı kararname ile Hamit ve Veysi isimli iki muhabere mülazım, Türk Ceza Kanunu ve Askeri Ceza Kanunu'na göre Komünizm propagandası suçundan hapis cezası almış ve ordudan ihraç edilmiştir. Bu durum 1932 tarihli ve 8731 numaralı kararnamede aşağıdaki şekliyle ifade edilmiştir (T.C. Cumhurbaşkanlığı Devlet Arşivleri Başkanlığı, 1932, Belge No: 30-11-1-0 / 71-17-3):

Orduyu isyana teşvik mahiyetinde görülen Komünist beyannamesi tap ve tevzi eylemek ve komünistlere yardım etmek suçlarından maznun, muhabere mülazım Hamit ve Veysi Efendiler 9. Kolordu Askeri Mahkemesince, Askeri Ceza Kanunu'nun 94. Maddesi ve Türk Ceza Kanunu'nun 314. Maddesi mucebince Hamit Efendinin 8 ay, Veysi Efendinin 5 ay hapislerine, Askeri Ceza Kanunu'nun 32. Maddesi mucebince ordudan ihraçlarına tensip olunmuştur.

6 Mayıs 1940 tarihli Cumhurbaşkanı İsmet İnönü başkanlığında yapılan Bakanlar Kurulu kararı ile; Stalin'in hayatına ait resimler komünist propagandası mahiyetinde bulunmuştur. $\mathrm{Bu}$ resimler toplattırılmış ve ülkeye sokulması yasaklanmıştır. Bu durum Bakanlar Kurulu Kararı'nda aşağıdaki şekliyle ifade edilmiştir (T.C. Cumhurbaşkanlı̆̆ı Devlet Arşivleri Başkanlığı, 1940, Belge No: 30-18-1-2 / 91-41-15):

Stalin'in hayatma ait resimleri havi olup, Komünist propagandası mahiyetinde görüldü̈̆̈̈ için matbuat kanununun muaddel 51. Maddesine tefrikan toplattırılmış olan albümün memlekete sokulmasının yasak edilmesi; Dahiliye vekilliğinin 24/4/940 tarih ve 2100 sayılı tezkeresi ile yapılan teklifi üzerine İcra Vekilleri Heyetince 6 Mayıs 1940 tarihinde kabul olunmuştur.

11 Mayıs 1948 tarihli CHP Genel Sekreterliği'nin başbakana yazmış olduğu yazıda, son dönemlerde günlük, haftalık, aylık mecmua ve gazetelerde gizli komünistlik propagandası yapıldığı ve alenen hükümet şahsiyeti ve maneviyesinin tahkir edildiği belirtilmektedir. Yazıda ayrıca "Lalapaşa" isimli gazetede komünizm içerikli yazılar yazıldı̆̆ belirtilmektedir. Bu yazıya istinaden Başbakan Hasan Saka, Adalet Bakanı'na, siyasi ve gayri 
siyasi yayınlarda komünizm içerikli suç sayılacak yazılara rastlanıldığı takdirde gerekli yasal işlemlerin başlatılmasını ve kendisine bilgi verilmesini isteyen yazıyı göndermiştir (T.C. Cumhurbaşkanlığı Devlet Arşivleri Başkanlığı, 1948, Belge No: 30-1-0-0 / 42-252-1).

14 Ocak 1956 tarihinde Bağdat'ta, Lübnan, Ürdün, Irak, İran ve Türkiye arasında, Komünizmle mücadele konusunda bir toplantı yapılmıştır. Bu toplantıda Türkiye'yi, Milli Emniyet Hizmetleri Reisi, Korgeneral Behçet Türkmen ve Komünizmle Mücadele Müdürü, Mustafa Gürgün temsil etmiştir (T.C. Cumhurbaşkanlığı Devlet Arşivleri Başkanlığı, 1957, Belge No: 30-18-1-2 / 146-41-8). Bu toplantıda Komünizm aşağıdaki şekliyle tanımlanmıştır:
Insan hak ve hürriyetlerini tanımayan, ferdin şahsiyetine kıymet vermeyen, proleter diktatorya namı altında yalnız bir zümrenin tahakkümünü tesise çalışan, cemiyetin çoğunluğunu zulüm ve istibdat altında bulundurmak isteyen, gayesine vasıl olmak istediği memleketlerde ihtilallar çıkarmak ve müesses anayasa rejimini değiştirmek suretle iktidarı zorla ele almak isteyen yıkıcı bir rejimdir.

Yukarıda adı geçen toplantıda aşağıdaki konu başlıkları özelinde anlaşmalar imzalanmıştır (T.C. Cumhurbaşkanlığı Devlet Arşivleri Başkanlığı, 1957, Belge No: 30-18-1-2 / 146-41-8)

a) Komünizm faaliyetleri, neşriyatı ve idarecileri hakkında bilgi paylaşımında bulunmak,

b) Komünistlerin, toplantıya katılan üye devletlerin memleketlerinde barındırılmamaları için gereken tedbirlerin alınarak, üye devletlerin emniyet servislerine bilgi vermek,

c) Komünizmle mücadelede her türlü imkândan faydalanmak.

Soğuk Savaş'ın son bulmasıyla daha sık vurgulanan kimlik tartışmalarına, erken cumhuriyet döneminde de rastlamak mümkündür. Türkiye'de Şeyh Said isyanı, kimlik ekseninde algılanan tehditler boyutunda açılanabilecek özellikleri barındırmaktadır. Şeyh Said isyanının çıkış sebeplerine bakıldığında içeriden ve dışarıdan kaynaklanan sebeplere değinmek mümkündür. 13 Şubat $1925^{\prime}$ te Bingöl'de başlayan ve bölgeye hızla yayılan, resmi ideolojiye karşıtlık ve İngiltere müdahalesi gibi etkenleri barındırmaktadır (Miş, 2012, s. 108109). İsyan, o dönemde kimlik faktörünün önemli bir tehdit olarak tartışılmasına neden olmuştur. Mecliste bu tehdidin ortadan kaldırılması için acil olarak görüşülmüş ve olağanüstü tedbirlerin alınması kararlaştırılmıştır. Şeyh Said isyanının sebepleri arasında; özellikle Musul petrolleri konusundaki İngiliz-Türk uyuşmazlığının bir yansıması olarak İngiltere'nin söylemlerinde Kürt kimliğini kullanması, değerlendirilmesi gereken bir diğer faktördür (Miş, 2012, s. 108-109).

\section{Tartışma Sonuç ve Öneriler}

Türkiye Cumhuriyeti'nin kuruluş sürecindeki güvenlik politikalarında hareket noktasının bekâ olduğunu söylemek mümkündür. Osmanlı Devleti'nin son dönemlerinden itibaren başlayarak özellikle Birinci Dünya Savaşı ve sonrasında artarak devam eden işgal tehdidi, toprak kaybetme korkusu ve farklı kimlik temellerinde yaşanan ayrılma kaygıları yeni kurulan Türk Devleti'nin güvenlik kültürünün oluşumuna zemin hazırlamıştır. Bu minvalde Türkiye'de erken cumhuriyet döneminin güvenlik kültürünün oluşumunu tarihsel bağlam, Türkiye Cumhuriyeti'nin kurucu ideolojisi, yabancı devlet tehdidi ve coğrafi özellikler ekseninde açılayabiliriz. Türkiye Cumhuriyeti'nin kuruluşunda "Sevr Korkusu" olarak tanımlanan güvenlik endişesi, Türkiye Cumhuriyeti Devleti kurucu ideolojisinin güvenlik 
politikalarına da hâkim olmuştur. Bu bağlamda erken dönem Türkiye Cumhuriyeti'nin güvenlik kültürünün inşasında tarihsel mirasın etkisi olduğu gözlemlenmektedir. Türkiye Cumhuriyeti, Osmanlı İmparatorluğu ile sosyal pratikler (etkileşim) yoluyla inşa etmiş bir aktördür. Bu sebeple yeni Türkiye Cumhuriyeti'nin tehdit kavramsallaştırması da sosyal etkileşim sonucu oluşmuştur. Türkiye'nin erken cumhuriyet dönemi tehdit algılarına ve güvenlik politikalarına bakıldığında Osmanlı İmparatorluğu ile olan etkileşim dikkat çekmektedir.

Devletlerin, diğer devletlerle olan sosyal ilişkileri ve tehdit algılamaları, güvenlik politikalarına etki etmektedir. Sosyal yapıyı oluşturan devletlerin, kimlik tanımlamaları ve sosyal ilişkileri, devletlerin birbirleri hakkındaki konumlarını belirlemektedir. Osmanlı Devleti'nin son dönemlerinden itibaren inşa edilen İngiltere, Yunanistan vb. yabancı devlet kaynaklı tehditler, azınlıkların ve ülke içinde diğer devletlerle ilişkisi bulunan vatandaşların denetim ve kayıt altında tutulmasına neden olmuştur. Bu çerçevede Sovyet ve komünizm tehdidinin Türkiye özelinde değerlendirilmesi yapılırken klasik realizm açıklamalarını referans göstermek mümkündür.

Türkiye'de erken cumhuriyet döneminden itibaren farklı kimlik temellerinde yaşanan tehdit algıları özelinde, halkın uyarma ve aydınlatma yolu ile korunması yönünde söylemler geliştirilmiştir. Farklı kimlikler temelinde yapılan propagandanın kendine özel ince bir tekniği olmasından dolayı özellikle köylerde yayıldığı ve bu duruma acilen önlem alınması gerektiği devletin resmi belgelerinde ifade dilmiştir.

Türkiye'de erken cumhuriyet dönemi güvenlik algısının inşası ve güvenlik politikaları değerlendirildiğinde; Realizmin unsurlarını barındıran çok boyutlu bir güvenlik yapısının olduğunu söylemek mümkündür. Osmanlı imparatorluğu ile etkileşim çerçevesinde kurulan Türkiye'nin dış güvenlik algısının, iç güvenlik içerisinde çözündüğü ve kimlik temelinde devlet altı unsurların iç güvenlik politikalarının oluşumuna etki ettiği görülmektedir. Devletlerin etkileşimle inşa ettikleri güvenlik kültürü, zamanla sosyal bir gerçeklik haline gelse de değişmesi ve çeşitlenmesi olanaklıdır. Çünkü aktörlerin çıkarları değiştiğinde güvenlik ve tehdit kavramsallaştırması da değişecektir. Bu çalışmanın Türkiye'nin kuruluş sürecindeki güvenlik kültürüne, güvenlik endişeleri ve politikaları çerçevesinde ş̧ık tutacağı düşünülmektedir.

\section{Kaynakça}

Akgül A. S. (2011). Alg1 mı, Söylem mi? Kopenhag Okulu ve Yeni-Klasik Gerçekçilikte Güvenlik Tehditleri, Uluslararası İlişkiler Dergisi, 8(30): 43-73.

Aktaş, A. (2011). Güvenlikleştirme Yaklaşımı ve Türkiye'nin Ulusal Güvenlik Anlayışındaki Dönüşüm, Kırıkkale Üniversitesi Sosyal Bilimler Dergisi, Sayı: 1(2): 7-47.

Arı, T. (2013). Uluslararası İlişkiler Teorileri, 8. Baskı, Bursa: MKM Yayınları.

Aydın, M. ve Ereker, F. (2014). Türkiye'de Güvenlik: Algı, Politika, Yapı, Uluslararası İlişkiler Dergisi, 11(43): 127-156.

Aydin, M. (2004). Securitization of History and Geography: Understanding of Security in Turkey, Southeast European and Black Sea Studies, 3(2): 163-184.

Babaoğlu, R. (2015). Türkiye'nin Soğuk Savaş Düşünce Hayatı, Antikomünizm ve Amerika Etkisi, Siirt Üniversitesi Sosyal Bilimler Enstitüsü Dergisi, 1(4): 165-174. 
Balkan, A. Z. (2007). Soğuk Savaş Sonrasında Yeni Güvenlik Teorileri ve Türkiye'nin Güvenlik Algılamaları, 21. Yüzyıl Dergisi, 1(3): 35-50.

Balta, E. (2014). Küresel Siyasete Giriş, Uluslararası İlişkilerde Kavramlar, Teoriler, Süreçler, 1. Baskı, İstanbul: İletişim Yayınları.

Bilgin, P. (2005). Turkey's Changing Security Discourses: The Challenge of Globalisation", European Journal of Political Research, 44(1): 175-201.

Birdişli, F. (2011). “Ulusal Güvenlik Kavramının Tarihsel ve Düşünsel Temelleri”, Sütçü İmam Üniversitesi Sosyal Bilimler Enstitüsü Dergisi, 31(2): 149-169.

Çalkıvık, A. (2014). Soğuk Savaş ve Sonrası Güvenlik Siyaseti, (Ed: E. Balta), Küresel Siyasete Giriş, Uluslararası İlişkilerde Kavramlar, Teoriler, Süreçler, 1. Baskı, İstanbul: İletişim Yayınları, s. 281-299.

Çıtak, E. ve Şen, O. (2014). Uluslararası İlişkilerde Güvenlik, Teorik Değerlendirmeler, 1. Baskı, Ankara: Röle Akademik Yayınları.

Dağı, D. İ., Eralp, A., Keyman, E. F., Polat, N., Tanrısever, F. O., Yalvaç, F. ve Yurdusev, A. Nuri, (2013), Devlet, Sistem ve Kimlik, Uluslararası İlişkilerde Temel Yaklaşımlar, 14. Baskı, İstanbul: İletişim Yayınları.

Dedeoğlu, B. (2014). Uluslararası Güvenlik ve Strateji, 3. Baskı, İstanbul: Yeni Yüzyıl Yayınları.

Emekliler, B. (2011). “Thomas Hobbes ve John Locke'un Güvenlik Anlayışlarının Karşılaştırmalı Bir Analizi", Güvenlik Stratejileri Dergisi, 13: 99-123.

Eralp, A. (2014). Devlet ve Ötesi, Uluslararası İlişkilerde Temel Kavramlar, 8. Baskı, İstanbul: İletişim Yayınları.

Gül, M. (2016). Güvenlikteki Kavramsal Değişim ve Türkiye'nin Güvenlik Yaklaşımı ve Politikalarına Etkileri, Süleyman Demirel Üniversitesi İktisadi ve İdari Bilimler Fakültesi Dergisi, Cilt: 21(1): 303-320.

Gün, Ç. (2014). "Ulusal Güvenlik Politikalarının Belirlenmesinde İstihbaratın Rolü ve Önemi", Yayımlanmamış Yüksek Lisans Tezi, Ankara: Kara Harp Okulu, Savunma Bilimleri Enstitüsü.

Gürpınar, B. (2016). Türkiye'de Milli Güvenlik Söylemi ve Dış Politika”', 1. Baskı, İstanbul: Beta Yayınları.

Hobbes, T. (2016), Leviathan, (çev.), Semih Lin, Yapı Kredi Yayınları.

Küçükşahin, A. (2006). Güvenlik Bağlamında Risk ve Tehdit Kavramları Arasındaki Farklar Nelerdir ve Nasıl Belirlenmelidir?, Stratejik Araştırmalar Enstitüsü Güvenlik Stratejileri Dergisi, (4): 7-40.

Miş, N. (2012). Güvenlikleştirme Teorisi ve Türkiye'de Güvenlikleştirme Siyaseti 1923-2003, Yayımlanmamış Doktora Tezi, Sakarya: Sakarya Üniversitesi Sosyal Bilimler Enstitüsü.

Oğuzlu T. (2015). Güvenlik Kültürü ve Türk Dış Politikası, Bilig Dergisi, Kış, Sayı: 72: 233-250.

T.C. Cumhurbaşkanlığı Devlet Arşivleri Başkanlığı, Cumhuriyet Arşivi, (1932), Belge No: 3011-1-0 / 71-17-3, "Komünizm propagandası suçundan mahkûm olan Muh. Teğmen. Hamit ve Veysi'nin ordudan ihracı", 10.06.1932, (Erişim Tarihi: 19.12.2016).

T.C. Cumhurbaşkanlığı Devlet Arşivleri Başkanlığı, Cumhuriyet Arşivi, (1940), Belge No: 3018-1-2 / 91-41-15, "Stalin'in hayatına ait resimler bulunan ve komünizm propagandası yapması sebebiyle daha önce toplattırılmış olan albümün yurda sokulmasının yasaklanması", 06.05.1940, (Erişim Tarihi: 19.12.2016).

T.C. Cumhurbaşkanlığı Devlet Arşivleri Başkanlığı, Cumhuriyet Arşivi, Belge No: 490-1-0-0 / 63-240-4, "Şahıslar hakkındaki istihbarat bilgileri" (Erişim Tarihi: 19.12.2016). 
T.C. Cumhurbaşkanlığı Devlet Arşivleri Başkanlığg, Cumhuriyet Arşivi, (1948), Belge No: 301-0-0 / 42-252-1, “Komünizm propagandası yapan solcu neşriyat hakkında, gereken tedbirleri tespit etmek üzere CHP Komisyonu'nun görevlendirilmesi”, 08.06.1948, (Erişim Tarihi: 19.12.2016).

T.C. Cumhurbaşkanlığı Devlet Arşivleri Başkanlığı, Cumhuriyet Arşivi, (1957), Belge No: 30 18-1-2 / 146-41-8, "Türkiye ile Lübnan, Ürdün, Irak ve Iran arasında Tahran'da yapilacak komünizmle mücadele toplantısına Emin Çobanoğlu ile Turhan Deniz'in katılmaları", 28.08.1957, (Erişim Tarihi: 19.12.2016).

Thukydides, (2017), Peloponnessos Savaşları, (çev: F. Akderin), Belge Yayınları. 